Sains Malaysiana 47(6)(2018): 1311-1318

http://dx.doi.org/10.17576/jsm-2018-4706-28

\title{
Immobilization of Bovine Serum Albumin on the Chitosan/PVA Film
}

(Imobilisasi Serum Bovin pada Filem Kitosan/PVA)

\author{
Nurul Mujahidah AHMAd KHAIRUdDin*, Amalina MuHAmmad AFIFI, Nur Awanis Hashim, \\ SHAZA EVA MOHAMAD \& KATAYOON KALANTARI
}

\begin{abstract}
Chitosan/polyvinyl alcohol (Chitosan/PVA) blended film was prepared by direct blend process and solution casting methods. In order to reduce the swelling ratio and enhance the chemical and mechanical stability, Chitosan/PVA film was crosslinked with glutaraldehyde in order to produce Chitosan-g-PVA. Bovine serum albumin (BSA) was used as a model protein to incorporate into the Chitosan-g-PVA. The chemical structure and morphological characteristics of films were studied by FT-IR and scanning electron microscopy (SEM). Mechanical and physical properties of blended films such as tensile properties in the dry and wet states, water uptake and water contact angle measurement were characterized. Blending PVA and chitosan improved strength and flexibility of the films. Crosslinking with glutaraldehyde further improves the tensile strength and decrease the hydrophilicity of films. BSA immobilized on the Chitosan-g-PVA film was calculated as BSA encapsulation efficiency.
\end{abstract}

Keywords: Bovine serum albumin; chitosan; glutaraldehyde; polyvinyl alcohol

ABSTRAK

Filem Kitosan/polivinil alkohol (Kitosan/PVA) telah dihasilkan melalui proses pengadunan dan teknik pembentukan larutan. Dalam usaha untuk mengurangkan nisbah pembengkakan dan meningkatkan kestabilan mekanikal dan kimia, Kitosan/PVA filem telah ditaut silang dengan menggunakan glutaraldehid untuk menghasilkan Kitosan-g-PVA. Serum bovin albumin (SBA) telah digunakan sebagai model protein untuk dicampurkan ke dalam Kitosan-g-PVA. Struktur kimia dan ciri morfologi filem telah dikaji dengan menggunakan FT-IR dan mikroskop elektron pengimbas (SEM). Sifat mekanikal dan fizikal filem seperti sifat tegangan filem dalam keadaan kering dan basah, kadar pengambilan air dan pengukuran sudut sentuhan air dicirikan. Pengadunan PVA dan kitosan memperbaiki kekuatan dan keluwesan filem. Proses taut silang dengan glutaraldehid meningkatkan lagi kekuatan tegangan dan mengurangkan sifat hidrofili filem. Immobilisasi SBA pada filem Kitosan-g-PVA dinilai sebagai kecekapan pengkapsulan SBA.

Kata kunci: Glutaraldehid; kitosan; polivinil alkohol; serum bovin albumin

\section{INTRODUCTION}

Water produced by different domestic and industrial activities is known as wastewater. It contains various inorganic, organic and biological contaminants that are of environmental significance. These contaminants can create health hazards if discharged into streams or oceans without proper care and treatment. It is very important to develop and design a new type of water treatment system that is more efficient and environmentally friendly in terms of fabrication and application. Chitosan has shown favourable biocompatibility characteristics, as well as the ability to increase membrane permeability (Nakorn 2008). Chitosan is a natural polysaccharide formed during the deacetylation of chitin in alkaline condition. It is a low cost material that can be found in crustacean shells, which are waste from seafood industries. It consists of two attractive functional groups, amine (-NH2) and hydroxyl $(-\mathrm{OH})$ groups. Thereby, chitosan has been used in many applications including waste water treatment. Chitosan also has good film forming property, high mechanical strength and chemical resistance making it promising material (Svangariyaskul et al. 2006).

Even though chitosan has many good properties due to its functional groups, further treatments are usually done to improve the chemical and mechanical resistance. To improve chitosan properties and further diversify its application, various strategies have been adopted such as blending, chemical modifications and crosslinking (ElHefian et al. 2010). In particular, modification of chitosan by blending with polyvinyl alcohol, (PVA) is an attractive method hence providing new desirable characteristics to chitosan. PVA is a non-toxic and water soluble synthetic polymer which has good chemical stability and film forming ability. PVA is a hydrophilic material with a large number of hydroxyl groups which allows it to react with many types of functional groups. This strong point makes PVA a good candidate for biomaterials application. Addition of PVA to chitosan, improves the film forming ability and mechanical properties of chitosan (Danwanichakul \& Sirikhajornnam 2013). 
In addition, previous work explored an interesting route to modify chitosan functional groups mostly composed of amino groups by using glutaraldehyde as a crosslink agent (Viera \& Beppu 2005). Glutaraldehyde is an effective crosslink for chitosan membranes. Using of glutaraldehyde can block amino groups and turn chitosan structures more inert and resistance to acidic media. Glutaraldehyde is a 5-carbon molecules with two aldehyde functional groups $(\mathrm{H}-\mathrm{C}=\mathrm{O})$ which are highly reactive towards amines. Glutaraldehyde is a clear, colourless and pungent oily liquid that is soluble in water and alcohol. It is widely used in protein immobilization and crosslinking through amino groups. Amines $\left(-\mathrm{NH}_{2}\right.$ or $\left.-\mathrm{NH}_{3}^{+}\right)$are commonly found on the surface of microbial cells and proteins. When glutaraldehyde contact with these biological entities it will chemically modifies and crosslink them (Migneault et al. 2004).

In this work, Bovine serum albumin (BSA) was used as a model protein to incorporate into the Chitosan/PVA blend. Immobilization of protein on a film is a good approach to remove biomolecules such as proteins and enzymes with high efficiency. There are several reasons for using protein in an immobilized form. It provides convenient during handling, and helps to prevents contamination of the substrate with enzyme/protein or other compounds, which decreases purification costs. Various supports have been used for enzymes or protein immobilization such as synthetic organic polymers, biopolymers, hydrogels, smart polymers and inorganic supports (Katchalski-Katzir \& Kraemer 2000).

Our aim in this work was to produce a BSA functionalized Chitosan/PVA blend with good mechanical properties. Many types of water purification systems are inefficient, difficult to handle and not be able to recycle. Immobilization of naturally available protein such as bovine serum albumin may add functions to the Chitosan/PVA blend, thus some enzymes has been studied for the degradation of dyes, protein capture and killing bacteria. In previous study reported by Homaeigohar et al. (2013), bovine serum albumin (BSA) protein was immobilized on nanofibers membrane made of poly(acrylonitrile-co-glycidyl methacrylate) (PANGMA). Upon wetting during filtration and medium $\mathrm{pH}$ is above the isoelectric point of protein, the protein undergoes a conformational change. The conformational changes leads to emergence of functional groups and able bind to water molecules resulted of protein swelling and nanosolid to be filtered. Higher stearic hindrance from the swollen protein encourages the capturing of the bacteria, dyes and proteins. With continuous research study, it could optimally separate biomolecule pollutants from waste water streams and a new water purification system will be developed with capability to treat contaminated water.

\section{MATERIALS AND METHODS}

Chitosan (with molecular weight $8.96 \times 105 \mathrm{~g} / \mathrm{mole}$, degree of deacetylation $(\mathrm{DDA})=40 \%$ ) was obtained from SE Chemical Co. Ltd (Kyoto, Japan). PVA was purchased from
Sigma Aldrich with molecular weight of 89,000-98,000 and $99 \%$ hydrolysed. Glutaraldehyde solution (50 wt $\%$ in water) and Bovine Serum Albumin were purchased from Sigma Aldrich and Merck Chemicals, respectively. Acetic acid and Sodium Hydroxide were obtained from R\&M Chemicals and Systerm Chemicals, respectively. Phosphoric acid (85\%) was purchased from R\&M Chemicals. Comassie Brilliant Blue G250 was purchased from Sigma Aldrich.

\section{PREPARATION OF CHITOSAN/PVA FILM}

The chitosan powder $(2 \mathrm{w} / \mathrm{v} \%)$ was dissolved in $2 \%$ acetic acid by constant stirring followed by degassing the solution for $2 \mathrm{~h}$. After degassing, the solution was poured into the petri plate and was maintained in the oven at $60^{\circ} \mathrm{C}$ for 24 $\mathrm{h}$. The resulted dry films were immersed in 0.5 M Sodium Hydroxide for $2 \mathrm{~h}$ at room temperature to completely neutralize the acetic acid trapped in the film. Then, the wet film were peeled off from the glass plate, washed sufficiently with water and dried at room temperature for 24 h. PVA was dissolved in distilled water at $80^{\circ} \mathrm{C}$ with gentle stirring for $1 \mathrm{~h}$ to form a $9 \mathrm{w} / \mathrm{v} \%$ homogenous solution. Then, the chitosan solution was mixed with PVA solution in the volume ration of $6: 4.10 \mathrm{~mL}$ of mixed solution was cast in a petri plate and dried at $60^{\circ} \mathrm{C}$ for $6 \mathrm{~h}$. Then the petri plate with the dried film was immersed in $0.5 \mathrm{M}$ $\mathrm{NaOH}$ solution for $2 \mathrm{~h}$. The membranes were rinsed with distilled water to $\mathrm{pH} 7$. Then, the treated films were dried at room temperature for $24 \mathrm{~h}$. To immobilize the films, cross-linked Chitosan /PVA (Chitosan-g-PVA) films need to be produced. Therefore, solvent vapours is one of the technique to crosslink the films. Ch/PVA films were sealed in a glass desiccator saturated with glutaraldehyde vapours (50\% water) for $6 \mathrm{~h}$.

\section{IMMOBILIZATION OF BSA ON CHITOSAN/PVA FILM}

The cross-linked PVA/chitosan (Chitosan-g-PVA) was immersed in the BSA that was diluted in phosphate buffer solution (PBS) at pH6.8 with concentration of BSA, 1, 3 and 5 and $10 \mathrm{mg} / \mathrm{mL}$. The mixture was moderately shaken for $24 \mathrm{~h}$ at $25^{\circ} \mathrm{C}$. To remove all the unbound BSA, the membrane were taken out and washed several times by PBS buffer. Then, the BSA immobilized membranes were carefully washed with distilled water and dry at room temperature.

\section{BSA BINDING CAPACITY MEASUREMENT}

The amount of residual protein after immobilization was determined by using the Bradford's Method (Bradford 1976). BSA was used as a standard to draw the calibration curve. The amount of free BSA or BSA residual was measured by UV spectrophotometry at 595 $\mathrm{nm}$. The amount of bound BSA on the cross-linked PVA/ Chitosan films was estimated by deducting the amount of the residual BSA from the initial amount of BSA $(5 \mathrm{mg} /$ $\mathrm{mL}$ ). BSA binding capacity was calculated according to (2) (Frokjaer \& Otzen 2005). 


$$
\begin{aligned}
& \text { BSA } \\
& \text { binding } \\
& \text { capacity }
\end{aligned}=\frac{\begin{array}{l}
\text { Initial BSA amount }(\mathrm{mg} / \mathrm{mL})- \\
\text { Free BSA amount }(\mathrm{mg} / \mathrm{mL})
\end{array}}{\text { Total amount of BSA }(\mathrm{mg} / \mathrm{mL})}
$$

\section{CHARACTERIZATION}

\section{FOURIER TRANSFORM INFRARED SPECTROSCOPY (FTIR)}

Infrared spectra were obtained using Perkin-Elmer 2000 FTIR. FTIR test was done on film with 16 scans within the wave number range of $4000-400 \mathrm{~cm}^{-1}$. All FTIR spectra were recorded in transmittance unit and conducted to identify the chemical interactions occurring between films composed of chitosan, PVA, glutaraldehyde and BSA.

\section{WETTABILITY AND WATER UPTAKE}

In order to evaluate the hydrophilicity of films, static contact angle of the films was measured using a contact angle analysis system (Dataphysics Instrument OCA 15EC, Germany). The samples were placed on sample stage and levelled horizontally. A $5 \mu \mathrm{L}$ droplet was dispensed on the film surface using a micro syringe. The contact angles were measured to ensure symmetry and horizontal level and average of 3 measurements at different points on the same films were considered. The film samples were cut into $47 \mathrm{~mm}$ diameter size and dried in oven at $60^{\circ} \mathrm{C}$ for $1 \mathrm{~h}$. After initial weighing, samples were kept in beaker with $50 \mathrm{~mL}$ distilled water for $72 \mathrm{~h}$ and measuring the wet samples weight at different intervals after removing the excess water (Bangyekan et al. 2006).

$$
\text { Water uptake }=\frac{(\text { Wwet }- \text { Wdry })}{\text { Wdry }} \times 100 \%
$$

where $\mathrm{W}_{\text {wet }}$ and $\mathrm{W}_{\text {dry }}$ are the weight of samples in wet and dry conditions, respectively.

\section{MECHANICAL PROPERTIES OF FILM}

All films were used in dry and wet conditions, thus it is necessary to study the mechanical properties of films in both conditions. Samples were cut into rectangular shape with the dimension of $10 \times 60 \mathrm{~mm}$. The tensile strength measurements of the films were carried by a universal tensile testing machine (Shidmazu AGS-X Series) equipped with 50-N load cell at ambient temperature. The crosshead speed was $5 \mathrm{~mm} / \mathrm{min}$ and the gauge length was $30 \mathrm{~mm}$. For each kind of film, at least three samples were tested. For the wet condition samples, samples were collected after the water filtration test. In the water filtration test, the dried membrane with diameter $47 \mathrm{~mm}$ is placed in the membrane module. The membrane films were subsequently put in dead-end stirred cell filtration system and $300 \mathrm{~mL}$ water was passed through them under a 1 bar applied pressure. After the water filtration test, the wet membrane films were collected. The medium on the sample surfaces was absorbed with filter paper before tensile test was carried out.

\section{FIELD-EMISSION SCANNING ELECTRON MICROSCOPY (FESEM)}

The cross section sections of the dry films were studied using FESEM (Model Carl Zeiss Auriga). Pieces were cut from films and mounted in copper stubs. Samples were observed using an accelerating voltage of $5 \mathrm{kV}$ and magnification at $5000 \times$.

\section{RESULTS AND DISCUSSION}

\section{BSA BINDING CAPACITY MEASUREMENT OF FILM}

BSA binding capacity was determined in order to estimate the actual amount of BSA that bound on the Chitosan-g-PVA film. The initial amounts of BSA used in this experiment were $1,3,5 \mathrm{mg} / \mathrm{mL}$. The calculations follow equation (2), where the binding capacity was calculated by deducting the initial amount of BSA concentration and the residual amount of BSA concentration. From Figure 1, $5 \mathrm{mg} / \mathrm{mL}$ of protein concentration shows high percentage of BSA encapsulation efficiency, which is $67.34 \%$ compared to 1 and $3 \mathrm{mg} / \mathrm{mL}$ with BSA encapsulation efficiencies are $41.61 \%, 62.26 \%$. Roozbahani et al. (2014) also reported that BSA as a model protein was successfully embedded in Poly ( $\mathcal{E}$-caprolactone)/chitosan blend nanofibers. Immobilization of BSA on the Chitosan-g-PVA film occurred via the ionic interaction. During the immersion of films in BSA, some of the BSA might trap among the positive hydrophilic chains and some distributed in the outer hydrophilic area of water. This indicated that only $67.34 \%$ BSA bound on the films and balance which is the free amount of BSA might react with water molecules (Zhang et al.2010). Based on Figure 1 results, the higher protein concentration leads to more encapsulation efficiency. Previous study also reported that the encapsulation efficiency could be increased by dissolving protein at a $\mathrm{pH}$ above its isoelectric point ( $\mathrm{pH} 4.8$ ). In this work, BSA was dissolved in PBS at pH6.8, which above its isoelectric point. At this $\mathrm{pH}$, BSA would predominantly exhibit its highest negative charge at pH6.8 and could contribute to electrostatic interactions between BSA with positively charged $-\mathrm{NH}^{+}$groups on the backbone of chitosan (Calvo et al. 1997). Therefore, BSA with the concentration of 5 $\mathrm{mg} / \mathrm{mL}$ was selected as the optimum parameters. With the highest encapsulation efficiency it will be a favour for the membrane applications.

\section{FTIR SPECTRA OF FILM}

FTIR spectroscopy is one of the most vital methods to examine the BSA conformation after immobilization. Moreover, to study the compatibility and interaction between chitosan and PVA and also Chitosan/PVA and glutaraldehyde, FTIR measurements were taken and summarized in Figure 2. From this figure, chitosan has a peak at $3349 \mathrm{~cm}^{-1}$ which is from the $\mathrm{OH}$ - vibrations and also a peak at $1596 \mathrm{~cm}^{-1}$ which attributed to the bending vibration and deformation of $-\mathrm{NH}_{2}$. Peaks at $2871 \mathrm{~cm}^{-1}$ 


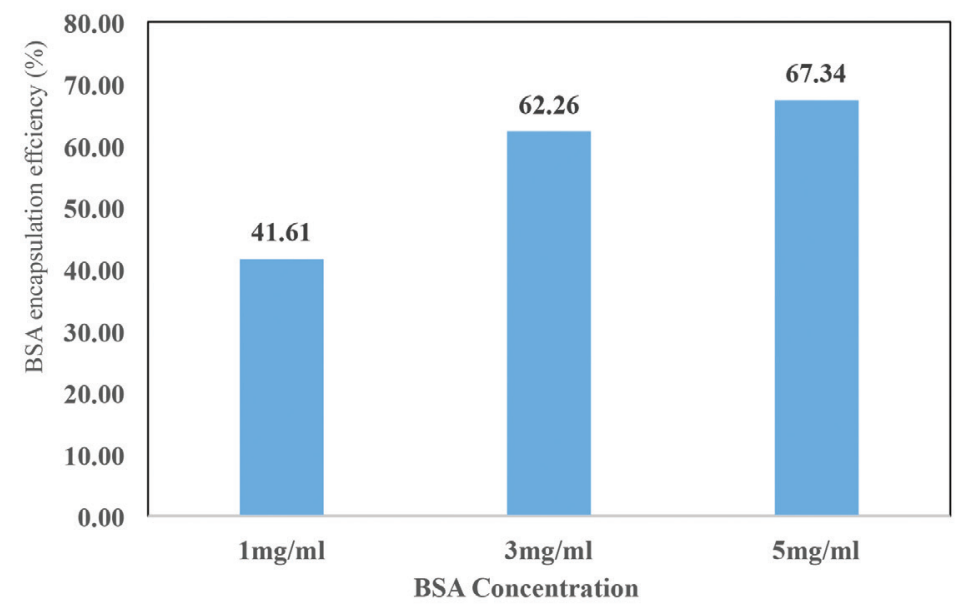

FIGURE 1. BSA encapsulation efficiency of Chitosan-g-PVA films

corresponding to $\mathrm{C}-\mathrm{H}\left(-\mathrm{CH}_{3}\right)$ were observed. Spectra of methylene groups from the bending vibrations around 1375 $\mathrm{cm}^{-1}$ and asymmetric vibrations of $\mathrm{CO}$ around $1150 \mathrm{~cm}^{-1}$ were present in chitosan. These are all the major peaks that attributed to the presence of chitosan in a membrane (Paluszkiewicza et al. 2011). With addition of PVA into chitosan, a new peak appeared at $1437 \mathrm{~cm}^{-1}$ which were caused by $-\mathrm{CH}-\mathrm{OH}$ bending vibration of PVA. Also, an increase in the intensity of $\mathrm{CH}$ group peak at around 2928 $\mathrm{cm}^{-1}$ was observed as PVA added into chitosan blend (Zhuang et al. 2012). In Figure 2, with glutaraldehyde crosslinking, PVA-g- $\mathrm{CH}$ shows an increment in the absorption peak of $1655 \mathrm{~cm}^{-1}$ due to $\mathrm{N}=\mathrm{C}$ bonds shoulders at 1562 and $1720 \mathrm{~cm}^{-1}$ due to ethylene and free aldehydes bonds, respectively. C-H stretch increase at $2936 \mathrm{~cm}^{-1}$ and the presence of aliphatic amino group leads to decrease in the intensity of the peak $1100 \mathrm{~cm}^{-1}$. It reflects that the crosslinking with glutraldehyde makes film more hydrophobic as amino groups are blocked with aliphatic chains (Beppu et al. 2007).

The main absorption bands of BSA were located at 1700 and $1540 \mathrm{~cm}^{-1}$, which correspond to the proteinrelated amide I and II absorptions as shown in Figure 2. The spectrum of the Chitosan-g-PVA containing BSA in Figure 2 shows both peaks for BSA as well as the characteristic peaks for Chitosan-g-PVA without BSA, which confirmed the presence of BSA in the blends (Roozbahani et al. 2014).

\section{WETTABILITY AND WATER UPTAKE} MEASUREMENT OF FILM

The contact angle technique is one of the most established methods for investigating the surface properties of polymers. It allows the geometric measurement or angle $\theta$ formed at the intersection of the liquid, gas and solid phases, thus providing a direct evaluation of surface wettability (Govindasamy et al. 2015). A higher contact angle $\left(>90^{\circ}\right)$ results in a more hydrophobic surface, while a lower contact angle $\left(<90^{\circ}\right)$ gives a more hydrophilic surface. However, with main interest of the films being biocompatible, a lower contact angle is much more desired

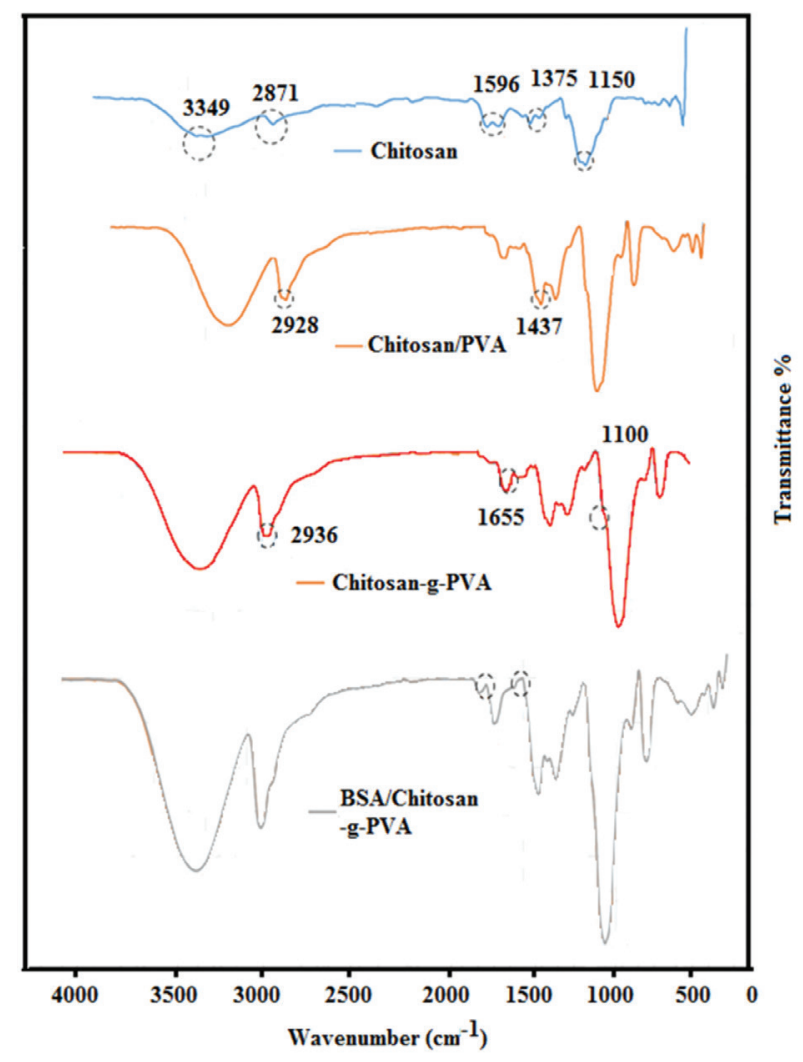

FIGURE 2. FTIR spectra of Chitosan, Chitosan/PVA, Chitosan -g-PVA and BSA/ Chitosan-g-PVA film

to enhance the hydrophilicity of film as it reflects the higher surface energy and better adhesion (Govindasamy et al. 2015). As shown in Figure 3, the degree of contact angle of the films increased in order of Chitosan/PVA $<$ Pure chitosan $<$ BSA/Chitosan-g-PVA<Chitosan-g-PVA. Chitosan/PVA has the lowest contact angle value, $55.70^{\circ}$ and Chitosan-g-PVA has the highest contact angle value, $79.80^{\circ}$. Chitosan/PVA membrane has resulted in lowest contact angle compared to pure chitosan. This demonstrated that adding PVA into chitosan could modify the wettability of chitosan film. This could be attributed to the availability of the $\mathrm{OH}$ - groups 
from the surface of polymers that cause the film to be more hydrophilic (Govindasamy et al. 2015). The water contact angle for Chitosan-g-PVA is slightly higher compared to Chitosan/PVA. This confirmed that with the presence of glutaraldehyde, films are more hydrophobic. Once the water drop on the film surface, the surface was blocked by the cross-linked surface of film therefore avoiding the water to spreading on top and penetrated into the film (Liu $\&$ Pan 2014). The contact angle value of BSA/Chitosan-gPVA slightly lower to Chitosan-g-PVA. This effect is caused by the presence of protein BSA on the film surfaces, which contains of amine and carboxyl groups. It could lead to higher interaction with water molecules during the wet states (Elbahri et al. 2012).

According to Figure 4, Chitosan/PVA film shows higher water uptake percentage and hydrophilicity compared to other films. This is greatly influenced by the PVA content in the blend. PVA is a water soluble polymer and blending chitosan with PVA will increase the water uptake. This is attribute to the increasing of hydrophilic groups $(-\mathrm{OH})$ in the blends (Svangariyaskul et al. 2006). It was also found that the stabilities of Chitosan/PVA film are poor in water. The water uptake of Chitosan/PVA drastically increases to $200 \%$ after $1 \mathrm{~h}$ being immersed in water. Therefore, a crosslinked Chitosan-g-PVA was produced and can be used for water filter applications. For cross-linked Chitosan-g-PVA film, the water uptake was evidently less compared to pure chitosan and Chitosan/PVA films. This is due to less flexible structures of the crosslinking network. Upon crosslinking, the water uptake dropped as much as $22 \%$ from Chitosan/ PVA. Crosslinking with glutaraldehyde decreases the water uptake of film. This is due to the entanglement of branched structures of Chitosan-g-PVA that increase the interactions between amine groups and hydroxyl groups, thereby decreasing hydrophilicity of the film (Danwanichakul \& Sirikhajornnam 2013). However, with the addition of BSA protein, the water uptake slightly increase compared to Chitosan-g-PVA. Glutaraldehyde or 1,5-pentanodial (OHC$(\mathrm{CH} 2) 3-\mathrm{COH}$ is a 5-carbon molecule with two aldehyde functional groups, $\mathrm{H}-\mathrm{C}=\mathrm{O}$ which are highly reactive with amines groups, $-\mathrm{NH}_{2}$ or $-\mathrm{NH}_{3}{ }^{+}$are commonly found on the protein surfaces. When glutaraldehyde comes into contact with biological entities, it chemically modifies or crosslink them. However, some of the protein ligands still present at the surface of the films, that may attribute to the interaction with the water molecules (Beppu et al. 2007).

\section{MECHANICAL STUDY OF FILM}

The tensile strength provides an indication of the strength and elasticity of the films. Blending of Chitosan/PVA improved the tensile strength of films. From Figure 5, Chitosan/PVA has higher tensile strength than pure chitosan film. Tensile strength of pure chitosan film is 22.56 MPa while tensile strength for Chitosan/PVA is 50.64 $\mathrm{MPa}$. The results showed the possibility of interaction between $\mathrm{OH}-$ and $-\mathrm{NH}_{2}$ groups in these two polymers. Blending leads to an intermolecular interaction between

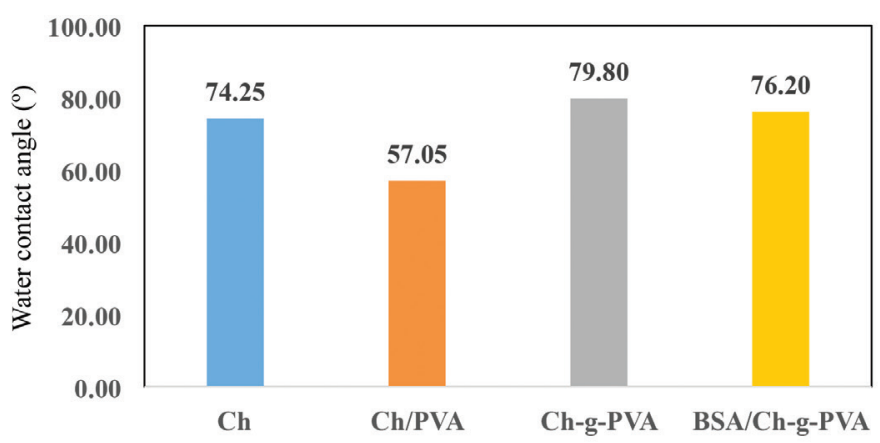

FIGURE 3. Water contact angle value for films

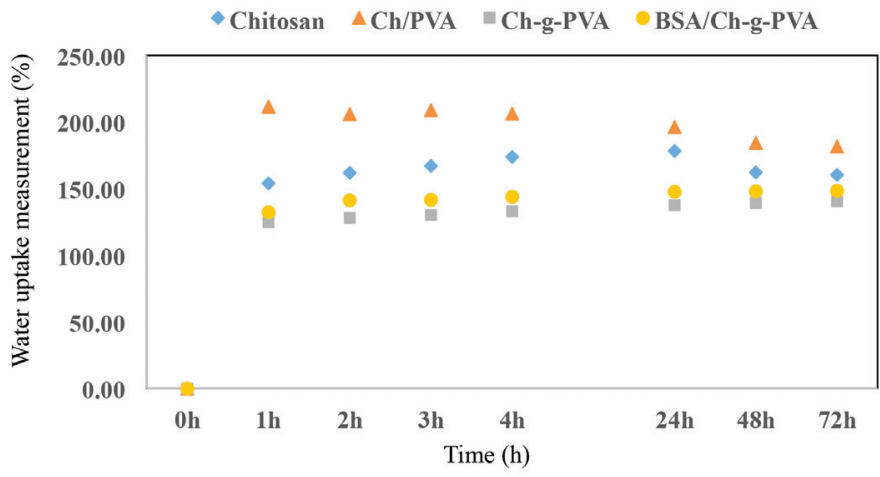

FIGURE 4. Water uptake measurement for films 
PVA and chitosan and this improves mechanical strength of the blends (Bahrami et al. 2002). Previous study also reported that tensile strength and elongation percentage may increase with increasing in the amount of PVA. This is mainly due to the strong hydrogen bonding between the $\mathrm{OH}$ group of PVA and the $\mathrm{OH}$ and $\mathrm{NH}_{2}$ groups of chitosan in the blends takes place. The intermolecular interactions between chitosan and PVA were also contributed from the positively charged polysaccharide chitosan moved towards to the negatively charge of the hydroxyl group of the polyvinyl alcohol (Abrahama et al. 2016). The conditions of Chitosan/PVA are different in both dry and wet conditions. Even though Chitosan/PVA absorbs more water than Chitosan during the water uptake measurement test, it shows higher tensile strength compared to Chitosan during the dry states. It can be justified that the stabilities of Chitosan/PVA film is very poor in water, as PVA is a highly hydrophilic materials. Therefore, Chitosan/PVA in the wet state show different performance as the polar groups from PVA may migrate towards the surface layer which is neighbouring with hydrophilic environment during immersion of samples in the water (Bahrami et al. 2002). Crosslinking with glutaraldehyde $\left(\mathrm{CH}_{2}\left(\mathrm{CH}_{2} \mathrm{CHO}\right)_{2}\right)$ in Chitosan/PVA membrane improves the tensile strength of the film. The crosslinking sample Chitosan-g-PVA shows higher tensile strength which is $56.01 \mathrm{MPa}$ compared to Chitosan/PVA film which is $50.64 \mathrm{MPa}$. The increase in the tensile strength is mainly due to the strong bond between both the aldehyde groups of glutaraldehyde with PVA chains. Cross-linker is a compound that can bind to the polymer chain with another chain either in covalent or ionic bonds form (Ma'ruf et al. 2015).

There are two different modes of crosslinking, which are intermolecular and internal crosslinking. Intermolecular crosslinking is crosslinking between different polymer molecules while crosslinking of a single polymer is called internal crosslinking or normally known as intramolecular crosslinking (Ma'ruf et al. 2015). From Figure 5, tensile strength of BSA/Chitosan-g-PVA is lower compared to Chitosan-g-PVA. The reaction between immobilized BSA and glutaraldehyde had been discussed and reported in previous works (Migneault et al. 2004). The mechanisms of protein crosslinking reactions remain open to speculate due to unclear reaction between proteins and glutaraldehyde. Extensive crosslinking may also affected the enzyme structure and distortion of the active site conformation may disturbing the retention of biological activity (Chui $\&$ Wan 1997). There are few factors that could attribute to the chemical reactions between glutaraldehyde and BSA such as nature of proteins, concentrations of both proteins and glutaraldehyde, $\mathrm{pH}$, temperature and the reaction time (Migneault et al. 2004). Thus extensive study should be made on the immobilized BSA (Chitosan-g-PVA), so that the conditions of both proteins and glutaraldehyde could be choose carefully to obtain good intermolecular crosslinking between molecules.

For the wet conditions test, only Chitosan-g-PVA and BSA/Chitosan-g-PVA films were tested. The tensile strength of Chitosan-g-PVA and BSA/Chitosan-g-PVA films decreased in the wet conditions. This could be due to the fact that immersion of the films in water affects the interfacial adhesion between the polymers. In a wet environment during the water filtration, the water molecules penetrate in the films and reduce the interfacial adhesion. In fact, water molecules which are free to travel through pores while those may dispersed and attached to the polar groups of polymers. In this case, PVA known as water soluble polymers and has large number of hydroxyl groups and may interact with water molecules.

This may cause swelling of films and makes the surface become soft. It is eventually lead to de-bonding between crosslinker and polymers which are PVA, chitosan and BSA resulted to decrease in the tensile strength of films (Azwa et al. 2013).

\section{MORPHOLOGICAL STUDY OF FILM}

The cross sections of Chitosan/PVA films without and with immobilized BSA are observed in Figures 6 and 7, respectively. In Figure 6, the cross section of the film shows it has homogenous blended structure of chitosan and PVA. While in Figure 7 shows cross section of film after immobilized with BSA. The image shows that the membrane surfaces were completely covered with the immobilized layer of BSA. Blended films of Chitosan/PVA with BSA protein exhibit a smooth cross section surface, which indicates a uniform distribution of Chitosan/PVA with BSA protein molecules. This is mainly caused by the interactions of hydrogen bonds between $-\mathrm{OH}$ and $\mathrm{NH}_{2}$ groups from PVA and chitosan. With the absorption of BSA into Chitosan/PVA film, it will attribute to higher amino group content and therefore improved the interactions

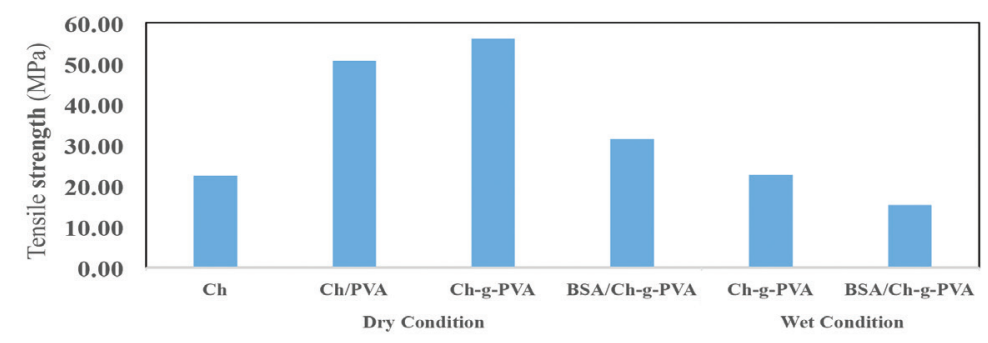

FIGURE 5. Tensile strength for different blend of samples 


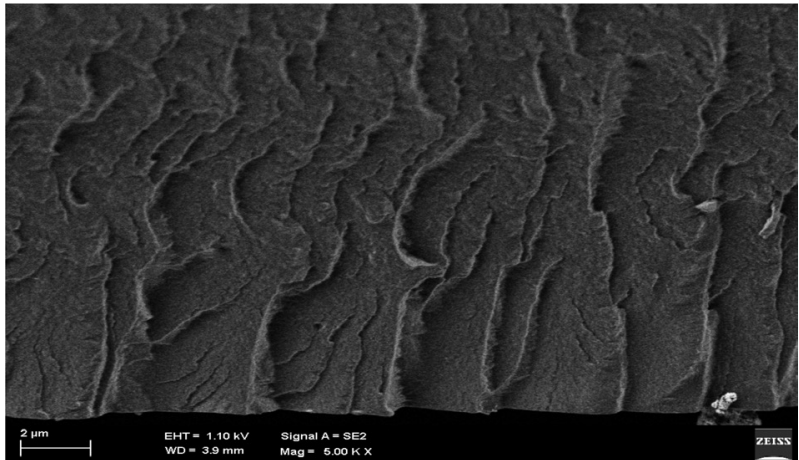

FIGURE 6. SEM micrograph showing the cross section of $\mathrm{Ch} /$ PVA film before immobilized with BSA

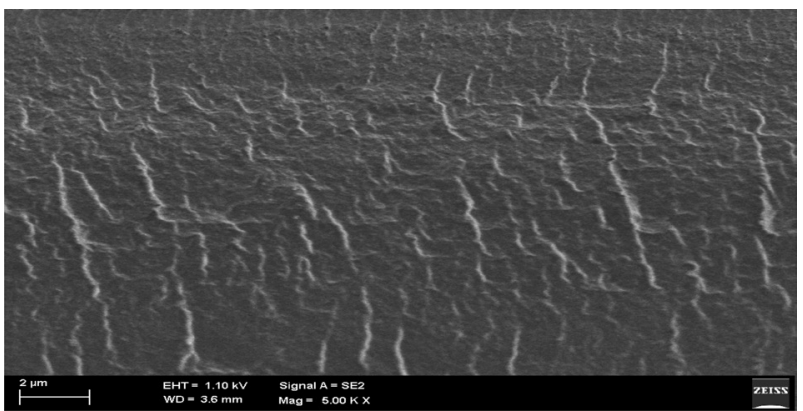

FIGURE 7. SEM micrograph showing the cross section of $\mathrm{Ch} / \mathrm{PVA}$ film after immobilized with BSA

between chitosan and PVA (Kim et al. 2017; Riyasudheen 2012).

\section{CONCLUSION}

Blended films of chitosan and PVA were prepared at different blend ratios and displayed good miscibility between chitosan and PVA. Swelling behavior and wettability of films showed higher water uptake after blend with PVA compared to the pure chitosan film. With addition of crosslinking agent, glutaraldehyde improves the tensile strength and decrease the hydrophilicity of films. $67.34 \%$ of BSA successfully immobilized on Chitosan-g-PVA film.

\section{ACKNOWLEDGEMENTS}

The authors would like to thank the financial support from University of Malaya Research (Grant RP034A-15AET) and Fundamental Research Grant Scheme (FRGS-FP0262014B)

\section{REFERENCES}

Abrahama, A., Soloman, P.A. \& Reijini, V.O. 2016. Preparation of chitosan-polyvinyl alcohol blends and studies on thermal and mechanical properties. Procedia Technology 24: 741-748.

Azwa, Z.N., Yousif, B.F., Manalo, A.C. \& Karunasena, W. 2013. A review on the degradability of polymeric composites based on natural fibre. Materials and Design 47: 424-442.
Bradford, M.M. 1976. A rapid and sensitive method for the quantitation of microgram quantities of protein utilizing the principle of protein-dye binding. Analytical Biochemistry 72(1-2): 248-254.

Bangyekan, C., Aht-Ong, D. \& Srikulkit, K. 2006. Preparation and properties evaluation of chitosan-coated cassava starch films. Carbohydrate Polymers 63(1): 61-71.

Beppu, M.M., Vieira, R.S., Aimoli, C.G. \& Santana, C.C. 2007. Crosslinking of chitosan membranes using glutaraldehyde: Effect on ion permeability and water absorption. Journal of Membrane Science 301(1-2): 126-130.

Bahrami, S.B., Kordestani, S.S., Mirzadeh, H. \& Mansoori, P. 2002. Poly (vinyl alcohol) - chitosan blends: Preparation, mechanical and physical properties. Iranian Polymer Journal 12(2): 139-146.

Calvo, P., Lopez, C.A., Jato, J.C.V. \& Alonso, M.J. 1997. Chitosan and chitosan/ethylene oxide-propylene oxide block copolymer nanoparticles as novel carriers for proteins and vaccines. Pharmaceutical Research 14(10): 1431-1436.

Chui, W.K. \& Wan, L.S. 1997. Prolonged retention of crosslinked trypsin in calcium alginate microspheres. Journal of Microencapsulation 14(1): 51-61.

Danwanichakul, P. \& Sirikhajornnam, P. 2013. An investigation of chitosan-grafted-poly(vinyl alcohol) as an electrolyte membrane. Journal of Chemistry 2013: Article ID. 642871.

Elbahri, M., Homaeigohar, S., Abdelaziz, R., Dai, T., Khalil, R. \& Zillohu, A.U. 2012. Smart metal-polymer bionanocomposites as omnidirectional plasmonic black absorber formed by nanofluid filtration. Advanced Functional Materials 22(22): 4771-4777.

El-Hefian, E.A., Nasef, M.M. \& Yahaya, A.H. 2010. The preparation and characterization of chitosan/poly (vinyl alcohol) blended films. Journal of Chemistry 7(4): 12121219.

Frokjaer, S. \& Otzen, D.E. 2005. Protein drug stability: A formulation challenge. Nature 4(4): 298-306.

Govindasamy, K., Ramli, M.H., Pasbakhsh, P., Pushpamalar, V. \& Salamatinia, B. 2015. Chitosan/cellulose/halloysite membranes produced using solvent casting method. Polymers \& Polymer Composites 23(5): 325-332.

Homaeigohar, S., Dai, T.H. \& Elbahri, M. 2013. Biofunctionalized nanofibrous membranes as super separators of protein and enzyme from water. Journal of Colloid and Interface Science 406: 86-93.

Kim, U.J., Lee, Y.R., Kang, T.H., Choi, J.W., Kimura, S. \& Wada, M. 2017. Protein adsorption of dialdehyde cellulosecrosslinked chitosan with high amino group contents. Carbohydrate Polymers 163: 34-42.

Katchalski-Katzir, E. \& Kraemer, D.M. 2000. A carrier for immobilization of enzymes of industrial potential. Journal of Molecular Catalysis B-Enzymatic 10(1-3): 157-176.

Liu, L. \& Pan, Z. 2014. Properties of hydrophilic chitosan/ polysulfone nanofibrous filtration membrane. Journal of Engineered Fibers and Fabrics 9(1): 76-86.

Migneault, I., Dartiguenave, C., Bertrand, M.J. \& Waldron, K.C. 2004. Glutaraldehyde: Behavior in aqueous solution, reaction with proteins, and application to enzyme crosslinking. Biotechniques 37(5): 790-802.

Ma'ruf, M.T., Siswomihardjo, W., Soesatyo, M.H. \& Tontowi, A.E. 2015. Effect of glutaraldehyde as a crosslinker on mechanical caharacteristics of catgut reinforced polyvinyl alchohol-hydroxyapatite composite as bone fracture fixation 
material. ARPN Journal of Engineering and Applied Sciences 10(15): 6359-6364.

Nakorn, P.N. 2008. Chitin nanowhisker and chitosan nanoparticles in protein immobilization for biosensor applications. Journal of Metals, Materials and Minerals 18(2): 73-77.

Paluszkiewicza, C., Stodolak, E., Hasika, M. \& Blazewicz, M. 2011. FT-IR study of montmorillonite-chitosan nanocomposite materials. Spectrochimica Acta Part A: Molecular and Biomolecular Spectroscopy 79(4): 784-788.

Roozbahani, F., Sultana, N., Almasi, D. \& Naghizadeh, F. 2014. Effects of chitosan concentration on the protein release behaviour of electrospun poly(e-caprolactone)/chitosan nanofibers. Journal of Nanomaterials 2015: Article ID. 747420 .

Riyasudheen, N., Aswini, K.K., Jayadevan, J. \& Athiyanathil, S. 2012. Bovine serum albumin immobilized-polyvinyl alcohol membranes: A study based on sorption, dye release and protein adsorption. Polymer-Plastics Technology and Engineering 51(13): 1351-1354.

Svangariyaskul, A., Huang, R.Y.M., Douglas, P.L., Pal, R., Feng, X., Chen, P. \& Liu, L. 2006. Blended chitosan and polyvinyl alcohol membranes for the pervaporation dehydration of isopropanol. Journal of Membrane Science 280(1-2): 815823.

Viera, R.S. \& Beppu, M. 2005. Mercury ion recovery using natural and crosslinked chitosan membranes. Journal of the International Adsorption Society 11(1): 731-736.

Zhang, H.L., Wu, S.H., Tao, Y., Zang, L.Q. \& Su, Z. 2010. Preparation and characterization of water-soluble chitosan nanoparticles as protein delivery system. Journal of Nanomaterials 2010: Article ID. 898910.

Zhuang, P.Y., Li, Y.L., Fan, L., Lin, J. \& Hu, Q.L. 2012. Modification of chitosan membrane with poly(vinyl alcohol) and biocompatibility evaluation. International Journal of Biological Macromolecules 50(3): 658-663.
Nurul Mujahidah Ahmad Khairuddin*, Amalina Muhammad Afifi \& Katayoon Kalantari

Department of Mechanical Engineering

University of Malaya

50603 Kuala Lumpur, Wilayah Persekutuan

Malaysia

Nur Awanis Hashim

Department of Chemical Engineering

University of Malaya

50603 Kuala Lumpur, Wilayah Persekutuan

Malaysia

Shaza Eva Mohamad

Department of Environmental and Green Technology (EGT)

Malaysia Japan International Institute of Technology (MJIT)

Universiti Teknologi Malaysia

Jalan Sultan Yahya Petra, 54100 Kuala Lumpur

Malaysia

Amalina Muhammad Afifi \& Katayoon Kalantari

Centre of Advanced Materials (CAM)

Faculty of Engineering

University of Malaya

50603 Kuala Lumpur, Wilayah Persekutuan

Malaysia

*Corresponding author; email: nurul2209@gmail.com

Received: 21 August 2017

Accepted: 26 January 2018 